\title{
CYTOCHROME P450 2E1 PARTICIPATION IN THE PATHOGENESIS OF EXPERIMENTAL METABOLIC SYNDROME IN GUINEA PIGS
}

\author{
V. V. RUSHCHAK, M. O. CHASHCHYN \\ Institute of Molecular Biology and Genetics, National Academy \\ of Sciences of Ukraine, Kyiv; \\ e-mail:v.v.rushchak@gmail.com
}

In this work the experimental metabolic syndrome on the basis of protamine sulfate modeling in guinea pigs was reproduced and pathological processes in the liver of experimental animals were studied. We determined the level of free radicals and markers of liver damage in the blood of experimental animals. We investigated the liver glycogen content and $\mathrm{K}^{+}, \mathrm{Na}^{+}$-ATPase activity in the liver of experimental animals as well as measured the cytochrome P450 2E1 (CYP2E1) expression - one of the main factors of oxidative stress. Evidence of development of hepatotoxic processes, increasing of the CYP2E1 level as well as of the free radical level in the animals with metabolic syndrome were found. Using of CYP2E1 inhibitors had shown that the free radical level in the blood of experimental animals depended on the level of the enzyme expression and activity. The obtained results suggest that the changes in the CYP2E1 expression play an important role in the development of hepatotoxic processes upon experimental metabolic syndrome. It was assumed that pharmacological correction of the enzyme expression may be an important mechanism for the influence on the metabolic syndrome clinical course.

Key word s: CYP2E1; diabetes; experimental metabolic syndrome; oxidative stress; protamine sulfate.

$\mathrm{M}$ etabolic syndrome (MS) is a complex and multifactorial etiology medical condition. Specialists do not consider any of MS symptoms as a main symptom including abdominal obesity, since new data have been reported that abdominal obesity has ethnic related characteristics (for example, the eastern nations), and is not always associated with development of the metabolic syndrome. The development of MS diagnostic criteria is one of the most important tasks, however to consider the diversity of all processes in the human body at the development of this syndrome in one characteristic is an extremely difficult problem. Currently, in clinical practice several definitions of MS are used [1]. Thus, to develop new MS and DM (diabetes mellitus) models, the necessity of reconstruction of a broad spectrum of pathological processes that occur in humans upon these diseases must be considered.

It is known that guinea pigs, owing to certain organism peculiarities, such as blood lipid composition and the absence of endogenous vitamin $\mathrm{C}$, are the optimal model for the study of carbohydrate and lipid metabolism disorders [2, 3]. When modeling of MS in these animals, there is no extraneous influence of enhanced antioxidants secretion and blood atherogenic properties on the development of pathological processes. Upon prolonged intramuscular administration of protamine sulfate to guinea pigs a number of symptoms, indicating the development of systemic homeostasis disorders, were observed. In particular, carbohydrate metabolism disorder (hyperglycemia and reduction of glycogen store in the liver) and lipid metabolism disorder (increase in cholesterol level) as well as inflammatory processes in the liver and kidneys (increased level of ALT, AST, creatinine and microalbuminuria), disorder of insulin synthesis, degradation of $\beta$-cells and accumulation of free radicals were observed $[4,5]$. The symptoms mentioned above are typical in the development of MS and DM in humans.

It is known that oxidative damage to tissues has been implicated in the etiology and pathogenesis of chronic complications in several diseases [6]. It has been shown that the increased production of reactive oxygen species induced by hyperglycemia upon metabolic syndrome and subsequent glucose toxicity lead to the development of oxidative stress accompanied by a lesion of the pancreatic $\beta$-cells and hepatocytes [7]. Recent studies have suggested that the development of the pathological conditions, 
such as alcoholic and non alcoholic steatohepatitis, type 1 diabetes, hepatitis $C$ are associated with the increased level of the CYP2E1 expression (CYP2E1 is one of the cytochrome P450 isoforms) [8]. It has been explained by the fact that CYP2E1 is a powerful source of reactive oxygen species (ROS) [9], which makes it one of the substantial factors in the development of oxidative stress. It can be assumed that the development of the metabolic syndrome will also lead to an increase in the CYP2E1 expression and in the degree of hepatocytes damage, and the regulation of the enzyme expression will affect the pathological processes which accompany this disease [10].

In our work, using the specific protamine sulfate model for metabolic syndrome, we studied the development of hepatotoxic processes and changes in the level of the CYP2E1 expression in the liver of guinea pigs with MS. The correlation between the enzyme expression and activity and the development of pathological processes in experimental animals using specific CYP2E1 inhibitors was also investigated.

\section{Materials and Methods}

Experimental animals and diet. Male fourmonth-old guinea pigs (30 animals) weighing $450 \mathrm{~g}$ (on the average) from the vivarium of the Institute of Pharmacology and Toxicology of NAMS of Ukraine were used in the study. Most reagents and substrates were purchased from Sigma-Aldrich (St. Louis, MO). All animal experiments were performed in accordance with the rules and regulations of The European Convention for the Protection of Vertebrate Animals Used for Experimental and Other Scientific Purposes [11].

Animals were housed in individual stainless steel cages with a controlled $12 \mathrm{~h}$ light/ $12 \mathrm{~h}$ dark cycle at $20-23{ }^{\circ} \mathrm{C}$ and fed on a standard rodent diet. Blood sampling was carried out from the ear vein. Glucose level was measured using a glucometer Accu-Chek Active (Accu-Chek, Germany).

Induction of metabolic syndrome. The metabolic syndrome was induced by intramuscular injection of protamine sulfate $15 \mathrm{mg} / \mathrm{kg}$ twice a day for 5 weeks, followed by keeping animals under normal conditions for 2 weeks. Such scheme was selected given the results of our previous studies which showed that experimental animals exhibited clear signs of the metabolic syndrome two weeks after the last injection of protamine sulfate [12]. Intact ani- mals $(n=5)$ during this period were kept under normal conditions. Thereafter the blood of intact animals and animals with MS $(n=5)$ under light ether anesthesia was taken by dissection of the femoral vein. The animals were then decapitated.

The remaining animals were divided into 4 groups. The animals of the first group were administered intramuscularly quercetin at a dose of $20 \mathrm{mg} /$ $\mathrm{kg}$ for 2 weeks The animals of the second group were administered intramuscularly 4-methylpyrazole at a dose of $20 \mathrm{mg} / \mathrm{kg}$ for 2 weeks. The animals of the third group were orally administered disulfiram at a dose of $25 \mathrm{mg} / \mathrm{kg}$. The control group (MS*) was maintained under normal conditions for 2 weeks to control the development of pathological processes. Thereafter, the animals were euthanized according to the protocol described above.

Preparation of microsomal fraction and determination of CYP2E1 activity. The animals were decapitated at the same time of a day to avoid diurnal changes in the microsomal enzymes activity. Microsomal fraction was obtained according to the protocol described in [13]. P-nitrophenol hydroxylase activity was determined as the rate of 4-nitrokatehol formation per time unit per $1 \mathrm{mg}$ of protein [14]. The obtained values were expressed as nmol of nitrokate$\mathrm{hol} / \mathrm{min} / \mathrm{mg}$ of protein.

Western blot analysis of CYP2E1. The total proteins were isolated from liver homogenate according to a standard protocol for membrane proteins preparation (Abcam, UK). The obtained proteins were separated by polyacrylamide gel electrophoresis (50 mg/track) followed by transfer to nitrocellulose membrane (Biorad, USA). After treatment with $2 \%$ skimmed dry milk solution, the membrane was incubated with anti-CYP2E1 antibodies (1/400, by volume) for 1 hour. Primary antibodies were produced in the Department of Molecular Oncogenetics, Institute of Molecular Biology and Genetics, NAS of Ukraine. The membrane was washed and then incubated with anti-Rabbit IgG-HRP secondary antibodies (Sigma, $1 / 5000$, by volume) for $1 \mathrm{~h}$. Proteins were visualized by chemiluminescence. Protein concentration was normalized relative to amount of the control $\beta$-actin protein on the same gel track. Densitometry analysis was performed using ImageJ software (Wayne Rasband, NIH). The results of Western blot analysis were presented in relative units of the luminescence intensity of the target protein.

Histological analysis. The liver was fixed in neutral buffered formalin solution (10\%) and dehydrated in a graded ethanol series $(50,70,80,90$, 
95 and 100\%). Tissues were placed in Paraplast and cut to $4 \mu \mathrm{m}$-thick sections. Glycogen content and $\mathrm{K}^{+}, \mathrm{Na}^{+}$-ATPase activity were determined in the obtained samples [15]. The obtained tissue samples were examined under optical microscope Leica DM 1000.

The assessment of free radical level and blood biochemical parameters. The level of ROS was measured in blood of experimental animals by spectrofluorimetry using 2,7-dichlorofluorescein diacetate (2,7-DCFH-DA) probe as described previously [16]. The results are presented in arbitrary units of the fluorescence intensity of dichlorofluorescein (oxidized 2,7-DCFH-DA). Alanine aminotransferase (ALT), aspartate aminotransferase (AST), alkaline phosphatase activities, as well as content of serum cholesterol, creatinine and glucose were measured using an automatic biochemical analyzer Tokyo Boeki Prestige 24i (Japan) and sets of specific reagents.

Statistical analysis. The data are presented as average values \pm error of the arithmetic mean for 5 animals per group. Statistical processing was performed using Student's t-test (for 2 groups) [17]. Values with $P<0.05$ were considered statistically significant.

\section{Results and Discussion}

Biochemical and histological analysis. It is known that during development of metabolic syndrome, changes in tissue biochemical and morphological-functional parameters occur. The results of serum biochemical analysis of animals with MS are presented in Table 1. It was found that the typical MS symptoms such as hyperglycemia (nearly 2-fold increase in serum glucose level) and hyperlipidemia (more than 2-fold increase in cholesterol) occurred at the early stages of MS. It was also found that the development of MS in experimental animals was accompanied by hepatotoxicity, as evidenced by an increase in the content of cytolysis markers and hepatocytes necrosis markers, in particular more than 2-fold increase in ALT and alkaline phosphatase, and also 6-fold increase in AST compared to control. An increase in serum creatinine, the end product of nitrogen metabolism, which indicates acute or chronic renal failure, was observed.

Immunohistrochemical analysis of the experimental animals' liver was carried out to determine glycogen content and $\mathrm{K}^{+}, \mathrm{Na}^{+}$-ATPase activity, by the PAS-reaction according to Mac-Manus and by Vahshtein and Meisel methodology, respectively. Carbohydrate metabolism disorder is considered to be the main pathogenetic mechanism of the MS development. Normal liver cells contain a large amount of glycogen (Fig. 1, A, pink granules). It is known that type 2 diabetes is accompanied by elevated glucagon level and activated hepatic glycogenolysis. Decrease in the stain intensity of the slide (Fig. 1, B) indicates a decrease in the amount of glycogen, which is a typical pathological process upon MS and type 2 diabetes [18].

It is known that insulin activates the liver $\mathrm{K}^{+}, \mathrm{Na}^{+}$-ATPase. Insulin facilitates potassium inflow into the liver cells and this effect is not related to hormone influence on glucose transport. A fall in activity of this enzyme could indicate insulin deficiency. Changes in the $\mathrm{K}^{+}, \mathrm{Na}^{+}$-ATPase activity is a reversible process, since the insulin administration to animals with insulin deficiency completely restores the activity of sodium-potassium pump [19].

The obtained results showed that the enzyme activity significantly decreased in the liver tissue of experimental animals (Fig. 2, B) compared to the intact animals (Fig. 2, A). This may also indicate insulin deficiency and development of MS.

Hepatic glycogen level and $\mathrm{K}^{+}, \mathrm{Na}^{+}$-ATPase activity were slightly lower under inhibitors action,

Ta ble 1. Biochemical parameters of MS animals blood serum

\begin{tabular}{lcc|c}
\hline \multicolumn{1}{c|}{ Biochemical parameters } & Intact animals & MS & Control (MS*) \\
\hline Glucose, $\mathrm{mmol} / \mathrm{l}$ & $5.2 \pm 0.2$ & $11.2 \pm 0.4^{*}$ & $10.2 \pm 0.3^{*}$ \\
Cholesterol, mmol/l & $0.58 \pm 0.03$ & $1.27 \pm 0.10^{*}$ & $1.50 \pm 0.09^{*}$ \\
Creatinine, $\mathrm{mg} / \mathrm{l}$ & $18.95 \pm 0.50$ & $38.0 \pm 1.2^{*}$ & $40.0 \pm 1.1^{*}$ \\
ALT, arb.u./l & $37.5 \pm 2.6$ & $91.5 \pm 4.9^{*}$ & $107.0 \pm 6.2^{*}$ \\
AST, arb.u./l & $39.5 \pm 2.7$ & $268.0 \pm 12.1^{*}$ & $255.0 \pm 15.1^{*}$ \\
Alkaline phosphatase,arb.u./l & $68.75 \pm 1.20$ & $133.0 \pm 3.3^{*}$ & $126.0 \pm 4.1^{*}$ \\
\hline
\end{tabular}

The data are presented as average value \pm error, $n=5, * P<0.05$ relative to intact animals (see text for explanation). 
though significantly higher than in the MS animals (Fig. 1, C, 2, C).

Study of the CYP2E1 expression level. Cytochrome P450 system is a powerful source of free radical generation [20, 21]. First of all it concerns the CYP2E1 isoform, which is characterized by a high level of oxidase activity and the ability to produce free radicals, even in the absence of the substrate [22]. It was shown that increased production of free radicals upon some diseases owing to increase in the CYP2E1 expression can cause oxidative stress. This leads to the development of various complications, such as micro- and macroangiopathy, retinopathy, nephropathy, and others. This is why the study of the mechanisms for CYP2E1-dependent oxidative stress and correction of some manifestations of this pathology by regulating the CYP2E1 activity are extremely important.

To investigate the changes in CYP2E1 expression during the MS development, CYP2E1 activity and protein content were evaluated. It was found that CYP2E1 activity in the liver of experimental ani- mals in the early stages of MS was slightly higher compared to control, however it increased nearly 3-fold in the further disease development (MS*) (Fig. 3, A).

The changes in the CYP2E1 protein level during the MS development in experimental animals are shown in Fig. 3, B. A slight increase in the CYP2E1 protein content was observed in animals with MS, and CYP2E1 level in liver cells of experimental (MS*) animals increased almost 3-fold in progression of MS. Thus, it can be asserted that increasing of the enzyme activity is caused by an increase in the cells CYP2E1content.

Some studies indicated the important role of CYP2E1 in the ROS production and oxidative tissue damage [23, 24]. Therefore we investigated the ROS level in the blood of experimental animals with metabolic syndrome and relationship between ROS production and the level of CYP2E1 expression. It was shown that the development of pathological processes in experimental animals was accompanied by an increase in free radical level, which was almost
$A$

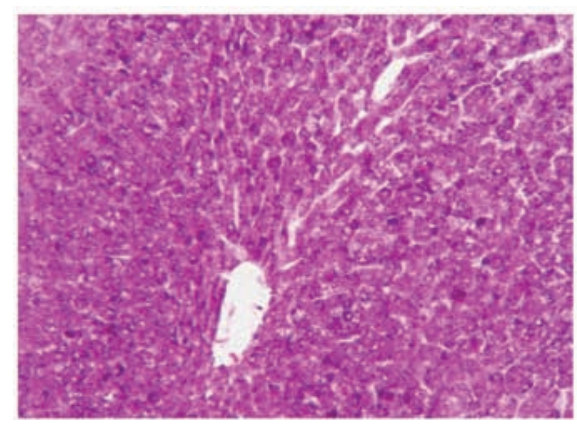

$B$

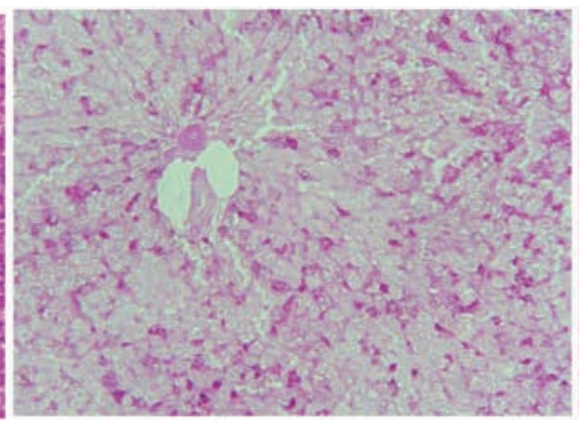

C

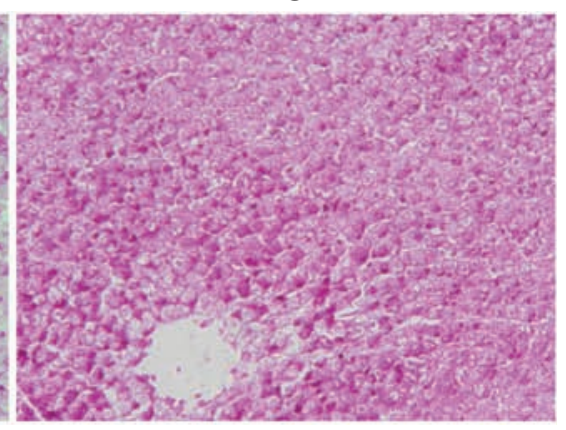

Fig. 1. Histochemical assessment of the glycogen content in liver cells (PAS-reaction according to MacManus). Leica DM 1000, 400 x. A - intact animals, B - control group (MS*), C-metabolic syndrome + quercetin

A

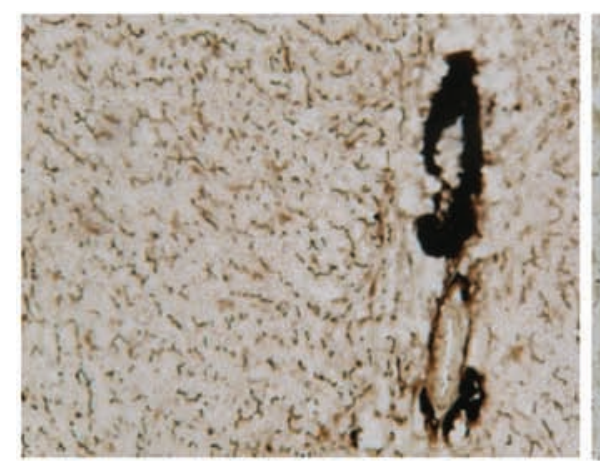

$B$

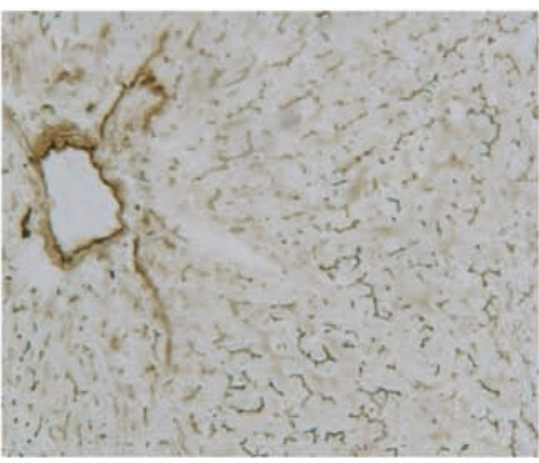

C

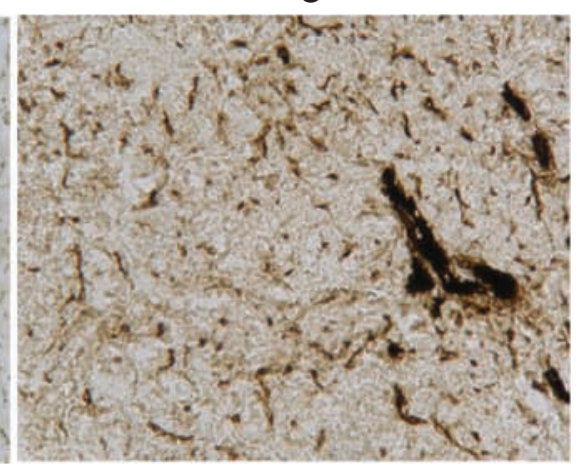

Fig. 2. Histochemical assessment of $\mathrm{K}^{+}, \mathrm{Na}^{+}$-ATPase in liver cells. Leica DM 1000, $400 \mathrm{x}$. A - intact animals, $B$ - control group (MS*), C-metabolic syndrome + quercetin 
A

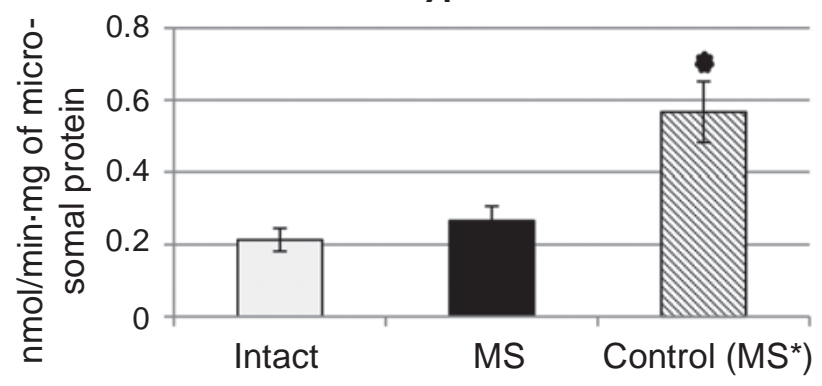

B

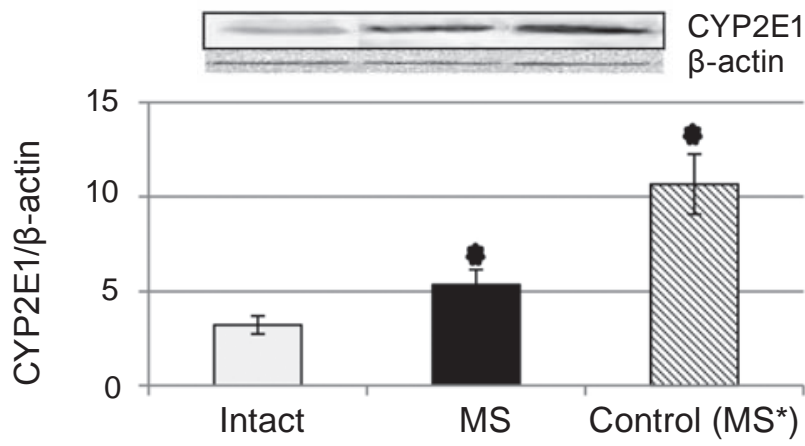

C

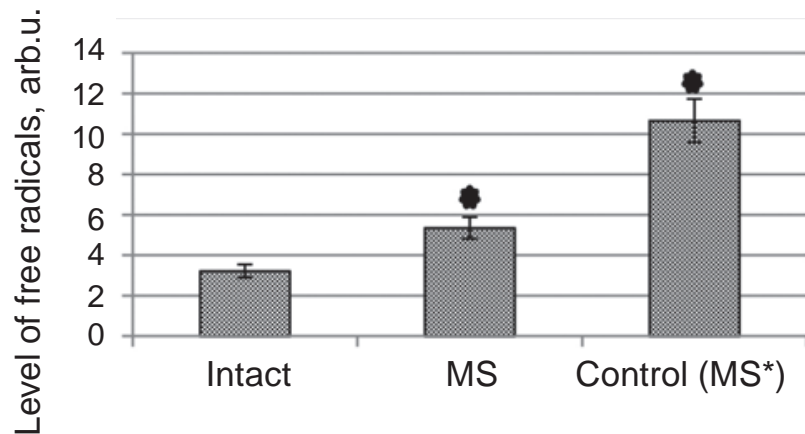

Fig. 3. Changes in CYP2E1 expression and activity in liver of experimental animals during modeled metabolic syndrome. A - cytochrome P450 2E1 activity; $B$ - protein CYP2E1 level; $C$ - accumulation of free radicals in leukocytes of experimental animals during metabolic syndrome development. * $P<0.05$ relative to intact group, $n=5$

2-fold higher compared with intact animals in the early stages of MS and 4-fold higher at further development of pathology (MS*) (Fig 3, B).

Investigating CYP2E1-dependent processes in experimental animals with MS, we compared blood biochemical parameters at various levels of the CYP2E1 activity depending on the effect of enzyme inhibitors, namely disulfiram, 4-methylpyrazole and quercetin.
As it is seen in Fig. 4, A, the inhibitors reduce (in varying degree) the liver CYP2E1 activity. Quercetin exhibited the most inhibitory effect at the given doses, 4-methylpyrazole - the least inhibitory effect. A significant decrease in the enzyme activity under the quercetin action confirms the results of computer modeling, concerning its efficacy in CYP2E1 inhibition.

The assessment of CYP2E1 content in liver cells revealed that protein level decreased proportionally to its activity. As it is seen in Fig. 4, B, 4-methylpyrazole affects more protein CYP2E1 content than its activity, whereas quercetin, on the contrary, is a potent inhibitor of the enzyme activity.
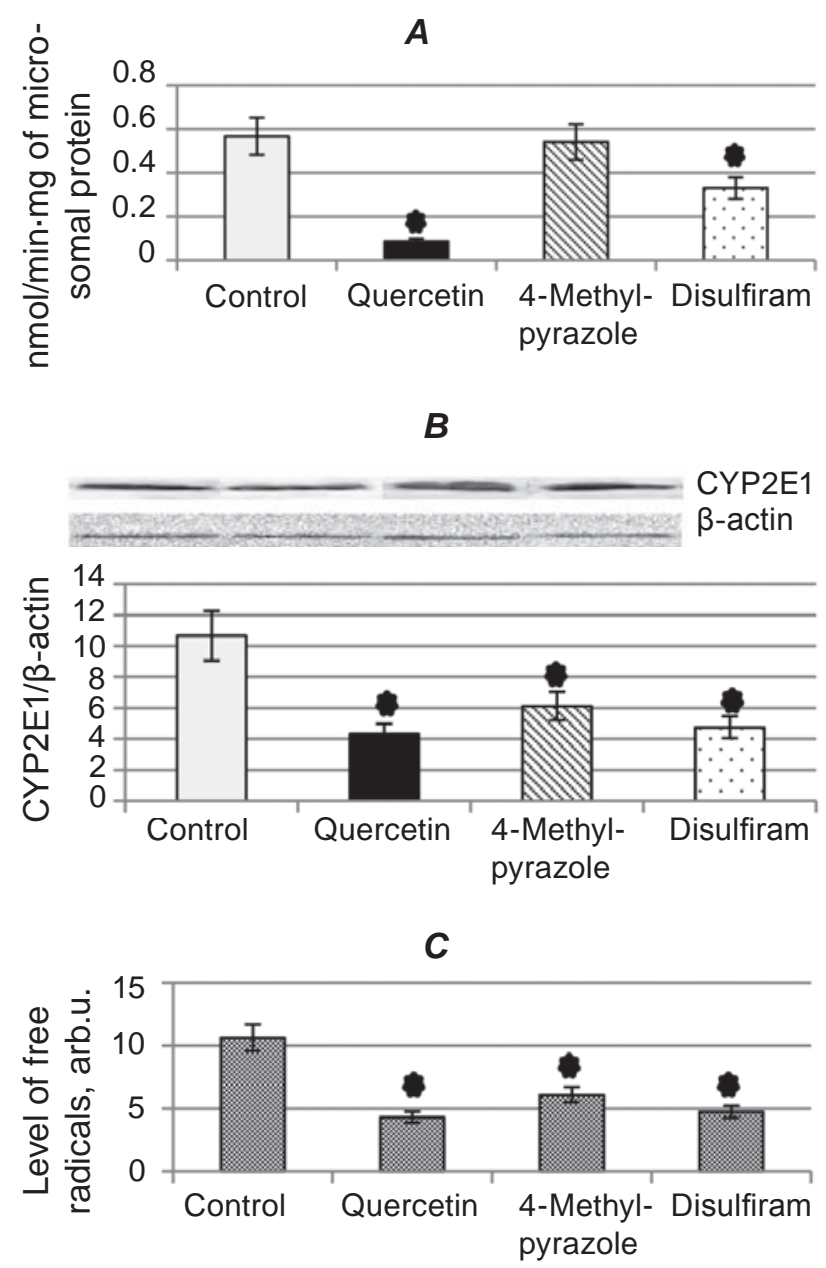

Fig. 4. Changes in CYP2E1 expression and activity in liver of experimental animals with $M S$ in the presence of CYP2E1 inhibitors: A - cytochrome P450 2E1 activity; $B$ - protein CYP2E1 level; $C$ accumulation of free radicals in leukocytes of experimental animals. $* P<0.05$ relative to control group, $n=5$ 
The inhibitors prevent the increase in free radical level, thereat quercetin and disulfiram lead to a slight decrease in the free radical level compared to that at the beginning of the administration (Fig. 4, C).

The results of biochemical blood tests (Table 2) showed that the administration of CYP2E1 inhibitors to MS animals was accompanied by a tendency to normalization of blood biochemical parameters. Quercetin showed the most pronounced effect, in particular, 2-fold decrease in the cholesterol level and decrease in ALT, AST and ALP levels to the values in intact animals were observed. At the same time, the level of creatinine, one of the integral indicators of kidney condition, remained almost unchanged. It is worth noting that the administration of disulfiram was accompanied by less pronounced changes in biochemical parameters. This indicates the need for further studies of the disulfiram dosedependent effect.

It should be noted that a decrease in the protein content and CYP2E2 activity, as well as free radical level led to a decrease in the degree of oxidative damage to hepatocytes. This was evidenced by normalization of functional parameters of the liver, in cells of which the CYP2E1 expression was the highest. This suggests that liver damage in MS animals might be reversible. Thus liver functional parameters at the CYP2E1 inhibition by quercetin restored almost to the norm (Fig. 1, $C$, Table 1-2). Quercetin may possibly have such pronounced hepatoprotective effect owing also to its antioxidant properties. It was confirmed by the fact that a decrease in the levels of ALT, AST and ALP under the influence of 4-methylpyrazole and disulfiram was less pronounced than that of quercetin.

Thus in our work, hepatotoxic processes in guinea pigs during MS development were studied. The increase in blood free radical level, ALT, AST, alkaline phosphatase activities, as well as the decrease in glycogen content and the $\mathrm{K}^{+}, \mathrm{Na}^{+}$-ATPase activity in hepatocytes indicated a disorder of the structural-functional state of liver cells. In experimental animals two weeks after the onset of MS symptoms (group MS*), there were no significant changes in biochemical parameters that indicate the resistance in the symptoms and the formation of the systemic pathological processes inherent to MS.

It has been shown that the induction of CYP2E1 expression is one of the factors in the development of systemic oxidative stress in some diseases [25]. Increase in CYP2E1 expression and free radicals production results in oxidative damage to the liver cells. This leads to progressive carbohydrate metabolism disorders and progressive tissue and organ damages [26]. Thus the regulation of CYP2E1 expression might be an effective mechanism for the correction of systemic CYP2E1-dependent oxidative stress upon metabolic syndrome.

We have studied the relationship between changes in CYP2E1 expression and hepatotoxicity using three specific inhibitors. These inhibitors affect CYP2E1 through different mechanisms. Thus disulfiram works through prior conversion to diethyldithiocarbamate, which directly inhibits enzyme activity [27]. This inhibition of CYP2E1 activity can be attributed to disulfiram hepatoprotective properties in case of paracetamol liver damage.

CYP2E1 inhibition by 4-methylpyrazole [28] leads to a significant reduction of the manifestations of oxidative stress, hepatotoxicity and the formation of an aldehyde-protein adducts. Such properties are used in the development of drugs for the prevention of hepatotoxicity in cases of methanol and ethylene glycol poisoning. Literature data have shown results similar to ours, that is, 4-methylpyrazole exhibits relatively slight effect on CYP2E1 activity. Though it

Ta b le 2. Biochemical parameters of MS animals blood serum under the action of the CYP2E1 inhibitors

\begin{tabular}{l|c|c|c|c}
\hline \multicolumn{1}{c|}{ Biochemical parameters } & Control (MS*) & MS + quercetin & $\begin{array}{c}\text { MS + } \\
\text { 4-methylpyrazole }\end{array}$ & MS + disulfiram \\
\hline Glucose, mmol/l & $10.2 \pm 0.3$ & $8.65 \pm 0.30^{\#}$ & $9.1 \pm 0.3^{\#}$ & $8.1 \pm 0.2^{\#}$ \\
Cholesterol, mmol/l & $1.50 \pm 0.09$ & $0.71 \pm 0.06^{\#}$ & $0.72 \pm 0.07^{\#}$ & $0.79 \pm 0.09^{\#}$ \\
Creatinine, mg/l & $40.0 \pm 1.1$ & $36.0 \pm 1.2^{\#}$ & $38.0 \pm 1.4^{\#}$ & $41.5 \pm 1.2^{\#}$ \\
ALT, arb.u./l & $107.0 \pm 6.2$ & $59.5 \pm 3.5^{\#}$ & $86.0 \pm 4.7^{\#}$ & $85.0 \pm 4.3^{\#}$ \\
AST, arb.u./l & $255.0 \pm 15.1$ & $80.0 \pm 4.4^{\#}$ & $176.0 \pm 12.7^{\#}$ & $201.0 \pm 11.2^{\#}$ \\
Alkaline phosphatase,arb.u./l & $126.0 \pm 4.1$ & $81.0 \pm 2.8^{\#}$ & $113.0 \pm 3.1^{\#}$ & $108.5 \pm 4.4^{\#}$ \\
\hline
\end{tabular}

The data are presented as average value \pm error, $n=5$, ${ }^{\#} P<0.05$ relative to control (MS+). See text for explanation. 
has been shown that 4-methylpyrazole significantly reduced free radical level in hepatocytes cell culture, pre-incubated for one day in the medium with $100 \mathrm{mM}$ ethanol [29, 30]. This indicates that the antioxidant potential of 4-methylpyrazole is realized by reducing the CYP2E1 protein level and free radicals production.

Quercetin is widely used as an antioxidant and angioprotector [31]. Moreover, as we reported previously [32], quercetin can be highly effective inhibitor of CYP2E1.

Simultaneous changes in CYP2E1 expression and oxidative stress level suggests that, in particular, increased CYP2E1 expression and activity are key factors of liver cells oxidative damage upon the development of metabolic syndrome.

Thus it has been shown that the protaminesulfate model (with a high degree of similarity) reproduces liver pathologic processes, which is typical symptom of the MS development. It enables to use this model in pharmacological and toxicological studies of drugs for diabetes therapy. The obtained results have indicated the correlation between increased SYP2E1 expression in liver cells, increased free radicals production in blood and hepatotoxicity in animals with metabolic syndrome. It has been shown that a decrease in CYP2E1 activity under the influence of specific inhibitors leads to impairment of severity of hepatotoxicity in experimental animals with MS. Thus pharmacological regulation of CYP2E1 functions and through them the pathological processes which accompany metabolic syndrome may be quite possible. This approach can be useful for correction of pathological processes accompanied by increased CYP2E1 level.

\section{Acknowledgments}

The authors would like to thank A. K. Voronina and G. M. Shayakhmetova (Department of General Toxicology of Institute of Pharmacology and Toxicology NAMS of Ukraine); O. V. Maksymchuk and I. V. Rosokhatska (Department of Molecular Oncogenetics of Institute of Molecular Biology and Genetics) for their support.
The work was performed as part of the research on departmental subject Cytochrome P450 2E1 in oxidative damage to liver cells upon diabetes mellitus (2013-2017) No. 2.2.4.25 Code: 2.28.2.1.

\section{УЧАСТЬ ЦИТОХРОМУ \\ P450 2E1 У ПАТОГЕНЕЗI \\ ЕКСПЕРИМЕНТАЛЬНОГО \\ МЕТАБОЛІЧНОГО СИНДРОМУ \\ В МОРСЬКИХ СВИНОК}

\section{B. В. Рущฺак, М. О. Чащин}

$$
\begin{aligned}
& \text { Інститут молекулярної біології та } \\
& \text { генетики НАН України, Київ; } \\
& \text { e-mail: v.v.rushchak@gmail.com }
\end{aligned}
$$

У роботі відтворювали експериментальний метаболічний синдром на основі протамінсульфатного моделювання та досліджували патологічні процеси в печінці морських свинок. У крові дослідних тварин визначали вміст вільних радикалів та маркерів пошкодження печінки. Гістохімічним методом досліджували вміст глікогену в печінці та активність $\mathrm{K}^{+}, \mathrm{Na}^{+}-$ АТРази, а також визначали рівень експресії цитохрому P450 2Е1 (CYP2Е1) - одного з головних факторів розвитку оксидативного стресу. У тварин із метаболічним синдромом було виявлено ознаки розвитку гепатотоксичних процесів, зростання рівня експресії цитохрому СYР2Е1 та підвищення вмісту вільних радикалів. Використання інгібіторів СYР2Е1 продемонструвало, що вміст вільних радикалів у крові дослідних тварин залежить від рівня експресії та активності ензиму. Показано також, що зміна експресії СYР2Е1 відіграє важливу роль у розвитку пошкодження печінки за метаболічного синдрому. Припускається, що фармакологічна корекція експресії CYP2Е1 може бути важливим механізмом впливу на перебіг цього захворювання.

К л ю ч о в і с л о в а: CYP2E1, діабет, експериментальний метаболічний синдром, оксидативний стрес, протамін-сульфат. 


\section{УЧАСТИЕ ЦИТОХРОМА P450 2E1 В ПАТОГЕНЕЗЕ ЭКСПЕРИМЕНТАЛЬНОГО МЕТАБОЛИЧЕСКОГО СИНДРОМА У МОРСКИХ СВИНОК}

\section{B. В. Рущак, Н. А. Чащин}

\section{Институт молекулярной биологии и генетики НАН Украины, Киев; e-mail: v.v.rushchak@gmail.com}

В работе воспроизводили экспериментальный метаболический синдром на основе протамин-сульфатного моделирования и исследовали патологические процессы в печени морских свинок. В крови экспериментальных животных определяли содержание свободных радикалов и маркеров повреждения печени. Гистохимическим методом исследовали содержание гликогена в печени и активность $\mathrm{K}^{+}, \mathrm{Na}^{+}$-АТРазы, а также определяли уровень экспрессии цитохрома $\mathrm{P} 450$ 2E1 (CYP2Е1) - одного из главных факторов развития оксидативного стресса. У животных с метаболическим синдромом были выявлены признаки развития гепатотоксических процессов, рост уровня экспрессии цитохрома СYР2E1 и повышение содержания свободных радикалов. Использование ингибиторов СYР2Е1 показало, что содержание свободных радикалов в крови подопытных животных зависит от уровня экспрессии и активности энзима. Также показано, что изменения экспрессии CYP2Е1 играет важную роль в развитии повреждения печени при метаболическом синдроме. Предполагается, что фармакологическая коррекция экспрессии CYP2E1 может быть важным механизмом влияния на ход данного заболевания.

К л ю че вы е с лов а: CYP2E1, диабет, экспериментальный метаболический синдром, оксидативный стресс, протамин-сульфат.

\section{References}

1. Diagnosis and treatment of metabolic syndrome, diabetes, pre-diabetes and cardiovascular diseases. Methodical recommendations of Working Group of metabolic syndrome, diabetes, pre-diabetes and CVD treatment, Ukrainian Association of Cardiology and Ukrainian Association of Endocrinology. Kyiv, 2009. 40 p. (In Ukrainian).
2. Fernandez ML. Guinea pigs as models for cholesterol and lipoprotein metabolism. J Nutr. 2001; 131(1): 10-20.

3. West KL, Fernandez ML. Guinea pigs as models to study the hypocholesterolemic effects of drugs. Cardiovasc Drug Rev. 2004; 22(1): 55-70.

4. Rushchak VV, Chashchyn MO. Insulin determination in pancreas of guinea pigs with metabolic syndrome. Fiziol Zh. 2014; 60(2): 4550. (In Ukrainian).

5. Vit VV, Tsiselskaya OYu, Tsiselskiy YuV, Levitskiy AP. Pathological changes in the retina of eyes rats with experimental 2 type diabetes mellitus and their correction by oral gels with biologically active substances. Ophthalmology. 2013; 10(4): 49-52. (In Russian).

6. Baynes JW. Role of oxidative stress in development of complications in diabetes. Diabetes. 1991; 40(4): 405-412.

7. Desco MC, Asensi M, Márquez R, MartínezValls J, Vento M, Pallardó FV, Sastre J, Viña J. Xanthine oxidase is involved in free radical production in type 1 diabetes: protection by allopurinol. Diabetes. 2002; 51(4): 1118-1124.

8. Gonzalez FJ, Gelboin HV. Role of human cytochromes P450 in the metabolic activation of chemical carcinogens and toxins. Drug Metab Rev. 1994; 26(1-2): 165-183.

9. Ekström G, Cronholm T, Ingelman-Sundberg M. Hydroxyl-radical production and ethanol oxidation by liver microsomes isolated from ethanol-treated rats. Biochem J. 1986; 233(3): 755-761.

10. Kovalev IE. Cytochrome P450 system and diabetes mellitus. Probl Endocryn. 2000; 46(2): 16-22. (In Russian).

11. Buhtiarova T, Stephanov O, Kovalenko V, Solovyov A, Bondarenko L, Shayakhmetova A. Medicines. Good laboratory practice. decree of Health Department of Ukraine No. 95 from 16.02.2009, 27 p. (In Ukrainian).

12. Rushchak VV, Kovalenko VM, Voronina AK, Kitam VO, Maksymchuk OV, Chashchyn MO. Optimization of animal model for investigation of pathogenesis of type 2 diabetes. Fiziol $\mathrm{Zh}$. 2012; 58(6): 29-35. (In Ukrainian).

13. Jeong $\mathrm{HG}$, Yun $\mathrm{CH}$. Induction of rat hepatic cytochrome P450 enzymes by myristicin. Biochem Biophys Res Commun. 1995; 217(3): 966-971. 
14. Reinke LA, Moyer MJ. p-Nitrophenol hydroxylation. A microsomal oxidation which is highly inducible by ethanol. Drug Metab Dispos. 1985; 13(5): 548-552.

15. Sarkisov D. Perov Y., editors. Microscopically technique. M.: Medicine. 1996, 544 p. (In Russian).

16. Bhagwat SV, Vijayasarathy C, Raza H, Mullick J, Avadhani NG. Preferential effects of nicotine and 4-(N-methyl-N-nitrosamine)-1-(3-pyridyl)1-butanone on mitochondrial glutathione S-transferase A4-4 induction and increased oxidative stress in the rat brain. Biochem Pharmacol. 1998; 56(7): 831-839.

17. Lapach SN, Chubenko AV, Babuch PN. Statistics in science and business. Kyiv: Morion, 2002. 640 p. (In Ukrainian).

18. Strukov A, Serov A. Pathological anatomy. M.: Medicina, 1995. 688 p. (In Russian).

19. Boldyrev AA. Na/K-ATPase - properties and biological role. Soros Obrazov Zhurn. 1998; 4(9): 2-9. (In Russian).

20. Koop DR. Oxidative and reductive metabolism by cytochrome P450 2E1. FASEB J. 1992; 6(2): 724-730.

21. Yang CS, Yoo JS, Ishizaki H, Hong JY. Cytochrome P450IIE1: roles in nitrosamine metabolism and mechanisms of regulation. Drug Metab Rev. 1990; 22(2-3): 147-159.

22. Guengerich FP, Kim DH, Iwasaki M. Role of human cytochrome P-450 IIE1 in the oxidation of many low molecular weight cancer suspects. Chem Res Toxicol. 1991; 4(2): 168-179.

23. Surbrook SE Jr, Olson MJ. Dominant role of cytochrome P-450 2E1 in human hepatic microsomal oxidation of the CFC-substitute 1,1,1,2-tetrafluoroethane. Drug Metab Dispos. 1992; 20(4): 518-524.
24. Marí M, Cederbaum AI. Induction of catalase, alpha, and microsomal glutathione S-transferase in CYP2E1 overexpressing HepG2 cells and protection against short-term oxidative stress. Hepatology. 2001 Mar;33(3):652-61.

25. Jaeschke H, Gores GJ, Cederbaum AI, Hinson JA, Pessayre D, Lemasters JJ. Mechanisms of hepatotoxicity. Toxicol Sci. 2002; 65(2): 166-176.

26. Schattenberg JM, Wang Y, Singh R, Rigoli RM, Czaja MJ. Hepatocyte CYP2E1 overexpression and steatohepatitis lead to impaired hepatic insulin signaling. J Biol Chem. 2005; 280(11): 9887-9894.

27. Pentiuk OO, Kachula SO, Herych OKh. Cytochrome P450 2E1. Polymorphism, physiological function, regulation, and role in pathology. Ukr Biokhim Zhurn. 2004; 76(5): 16-28. (In Ukrainian).

28. Swaminathan K, Clemens DL, Dey A. Inhibition of CYP2E1 leads to decreased malondialdehydeacetaldehyde adduct formation in VL-17A cells under chronic alcohol exposure. Life Sci. 2013; 92(6-7): 325-336.

29. Gong P, Cederbaum AI. Nrf2 is increased by CYP2E1 in rodent liver and HepG2 cells and protects against oxidative stress caused by CYP2E1. Hepatology. 2006; 43(1): 144-153.

30. Yang SP, Medling T, Raner GM. Cytochrome P450 expression and activities in rat, rabbit and bovine tongue. Comp Biochem Physiol C Toxicol Pharmacol. 2003; 136(4): 297-308.

31. Boots AW, Haenen GR, Bast A. Health effects of quercetin: from antioxidant to nutraceutical. Eur J Pharmacol. 2008; 585(2-3): 325-337.

32. Kitam VO, Chashchyn MO. Computer modeling of the human cytochrome P-450 2E1 complex formation. Ukr Biokhim Zhurn. 2010; 82(2): 94103. (In Ukrainian). 